\title{
PROJECTIONS NEED OF PASSENGER AND CARGO MOVEMENT AT SOEKARNO-HATTA INTERNATIONAL AIRPORT
}

\author{
Lia Alvianita ${ }^{1}$ \\ 1. STMT Trisakti Jakarta \\ $\bowtie$ Corresponding Author: liaalvianita@gmail.com
}

\begin{abstract}
This research was conducted to determine projections passenger numbers and cargo at Soekarno-hatta for next 10 years. From the process of analysis can be specified that for the calculation of the projection of the number of passengers and cargo at the Soekarno-Hatta Airport and the most appropriate method to use is a good method of trend analysis that has the highest coefficient value with the regression equation models for each of the categories, such as the number of arriving passengers $\mathrm{Y}=-11,272 \mathrm{x}^{2}+2,092,814 \mathrm{x}+23,778,625$ with $\mathrm{R}^{2}=$ 0.089 , the number of departing passengers $\mathrm{Y}=1,293,985 \mathrm{x}^{2}-4,594,289 \mathrm{x}+$ $24,053,873$ with $R^{2}=0.217$ the number of transit passengers $\mathrm{Y}=24,754 \mathrm{x} 2$ $365,743 \mathrm{x}+3,032,822$ with $\mathrm{R}^{2}=0.371$ as for the projection of the number of cargo can be used the equation $\mathrm{Y}=50,462,439 \mathrm{x}^{2}-188,365,612 \mathrm{x}+586,755,803$ with $\mathrm{R}^{2}$ $=0.262$. Soekarno-hatta airport is expected to be ready to face the increasing number of passengers and cargo by preparing and improve all the services and amenities.
\end{abstract}

Keywords: projection, trend analysis, passenger, cargo

\section{Introduction}

Indonesia is one of the members of the ASEAN countries which have the widest region and consists of thousands of Islands. Indonesia has ideals for connecting one region with other regions are integrated and structured. The selection of the mode of transportation that is effective and efficient to reach out to the whole community in Indonesia is absolute. Transport that can be used in Indonesia is very diverse, consisting of all kinds of transportation modes, ranging from transportation by land, sea, air, pipeline, and air transportation from the side., developments happen so rapidly from either the tools that support the transportation or technology used in its operational activities. Soekarno-Hatta Airport is the biggest airport and busy in Indonesia which has a large capacity to accommodate passengers who would use air transportation services both domestic and international. As the main airport of Soekarno-Hatta, Indonesia has a strategic role in terms of the Ministry of transport for visitors both aim to do business or as a transit airport to continue your journey to other locations Indonesian. 
Activities in Soekarno-Hatta Airport in a span of the last 5 years an increase in the amount of air traffic activity, although in the year 2015 had happened a decline in passenger numbers, but the trend of development of the Soekarno-Hatta Airport tend to increase every year. Improved quality of adequate facilities and infrastructure are indispensable to support the rate of growth of air traffic at Soekarno-Hatta Airport. Thus, in planning the development of the facilities of the Soekarno-Hatta Airport, then to do the analysis model needs the movement of passengers and goods at the Soekarno-Hatta Airport in order to predict the number of passengers and goods within the next few years.

This research aims to project its own growth rate of the number of passengers and goods within 10 years by using the method of Trend analysis and model of market share, as well as to determine the best model for projections of the number of passengers and goods until the year 2025 and predict the number of passengers and aircraft movements at the time of peak hours.

\section{Literature Review}

Passenger and Cargo

As per R. S. Damardjati (2001), Passenger is every person who is transported or to be transported in the aircraft or the agency carrying the transport. And passenger movement is every activities of the passenger at the airport such as arriving, departing, and transit from one terminal to another terminal.

According to Suharto and Eko Probo (2010), "Cargo is defined simply as all goods that are sent by air (aircraft), sea (ships), or land (container truck) that is usually for trade, both between regions/ cities in the country and between countries (international) known as export-import.

Forecasting

Forecasting (forecasting) is the process of estimating some requirements in the dating that includes requirements in the measure of 
quantity, quality, time, and location that is needed in order to meet the demand for goods and services. (Arman Judge Nasution, 2006)

In doing a planning needs in future it needs a strong planning as well as optimistic. Improvement of all facilities available at the airport, badly needed to support development and growth in the future, in addition serves to evaluate the influence of the ministries along with the presence of the development of new routes as well as an increase in the number of passengers and goods. Foreseeing the need in the future should be based on some of the things that became the basis of the estimation of the amount of goods and passengers, i.e. as follows (Elsa Trine, 2008):

a. The area is served by the airport.

b. Origin and destination of the trip.

c. Characteristics of population growth and population.

d. Economic characteristics of an area.

e. Consideration of the geographical factor.

f. The competition mode of aircraft with other modes. Alternative forecasting methods

According to Taylor III (2005.301) there are two methods of doing forecasting, time series method and causal methods, at both of these methods there are three factors that affect the assessment, namely:

1. Factor time series (time series), is a category of statistics technique that uses historical data to determine the behavior to come.

2. Factor regression, trying to mengembngkan the systematic relationship between items that are foreseen with the factor that causes these items have a particular behaviours, which is translated in the form of a regression model.

3. Qualitative Factors, trying to make forecasting by using judgment, opinion, and the opinion of the management.

In forecasting techniques in air traffic planning, science and knowledge of the magnitude of the burden of air traffic is much needed. As for burden or focus of air traffic itself can be divided into two, namely:

1. Passenger transport 
2. Transport of goods/cargo/post

Model Trend Analysis

Trend analysis is a simple general model that is commonly used for data time series and forecasting. The data used in this model is the data the number of passengers and goods within a certain time range from aspects of the review. This model can also serve to monitor the trend of the overall data from a long span of time that can be continuously prove that the existence of a related relationship will happen in the future that will be. As for some form of trend analysis models are commonly used:

- Method of regression-linear

- Exponential equations Method

- A modified exponential Method

Market Analysis Method

Methods of market analysis is a method used to analyze and study the problems of the market regarding the location, extent, nature, and the characteristics of the market. In aviation this method is a technique that is most frequently used in estimating demand and benefit the most general is in determining the part of the air traffic activity or the airport. Historical data from an airport were studied to determine the ratio of the air traffic or airport to the total national air traffic as well as ensure its tendency.

A method of stock market has the main advantage of such linkages on the sources of data available, which will reduce the cost forecast. However, there is also a major weakness in the dependencies in keteramalan (predictability) and the stability of the ratio that is the basis of that forecast and uncertainty on the part of the market in a specific application. (Elsa Trimukti, 2008)

\section{Method}

This study uses secondary data obtained or acquired from related parties as well as data available from government agencies, namely the Directorate General of air transportation, and the Central Bureau of statistics. The data is processed using a Method of forecasting (forecasting) 
to project needs and events that will occur in a certain period of time in the future by using the reference data in the past and now. These data are collected as the basis of calculation of the upcoming 10-year projections are related to the number of passengers and goods using the services of air traffic. By using some of the methods of calculation and different analysis can be taken a conclusion the best results from calculations and analyses are made.

In projecting the number of passengers and goods in the future, research conducted using the model of forecasting the trend analysis and market analysis method in which of these two methods will be determined and a comparison the best method to use.

\section{Discussion and Result}

The process of forecasting activities or projection of the needs and capacity of an airport must be based on the development of forecasting or forecasts. Trends from our trip in the future can be used as a basis of American in conducting performance assessment, achievement, and success of an airport in the face of the growth of the number of passengers as well as goods. The facilities already available else participate as reference of assessment of an airport can be categorized under prepared and development growth of air traffic. In addition, trends in travel can be used as ingredients of an evaluation process regarding the level of service of airports that can directly affect the growth and development of air traffic passengers, both in terms of delivery goods, the company pilots, and airport users other than passengers are widely and can be used as proposed in the development of programs assist airport remains on the main purpose of corridors and related policies in a comprehensive manner.

Model of forecasting the needs of air traffic

Model of trend analysis and market analysis method used in the process of calculation and forecasting of traffic volume of passengers and goods in air transport for the next performed a comparison of both methods. Of both of these methods will get the regression formula that shows the 
relationship between the present conditions against a projection of the future and the resulting regression of both of these methods will be compared to the next the most determined in accordance with the projected pattern and this regression formula to test whether it can be used to project the future State. A linear relationship between two variables that will be measured by whether or not a strong or the value of the correlation coefficient.

This correlation coefficient with a value, then a conclusion can be drawn will be the relationship of existing variables, where the value added or time of the variable $X$ will affect or have a positive or negative relationship toward the value of $Y$. Thus every addition or decline occurred from the end i.e. variable end will affect the end result that is sought from the variable $\mathrm{Y}$.

Model Trend Analysis Based on the growth of passengers and goods Model Of Trend Analysis For Passenger

Data the data used was the number of passengers coming, departing and transit at the Soekarno-Hatta Airport starting from year 2011 up to 2015 are obtained from the Directorate General of Air Transportation.

Table 1. The number of passengers of Soekarno-Hatta Airport of the year 2011-2015

\begin{tabular}{|c|c|c|c|c|}
\hline \multirow{2}{*}{ Years } & \multicolumn{2}{|c|}{ The Number Of Passengers } & \multirow{2}{*}{ Total } \\
\cline { 2 - 4 } & Arrive & Depart & Transit & \\
\hline 2011 & $24,525,301$ & $22,757,324$ & $2,867,274$ & $50,149,899$ \\
\hline 2012 & $28,789,230$ & $25,697,550$ & $3,285,982$ & $57,772,762$ \\
\hline 2013 & $14,651,927$ & $12,988,593$ & $1,611,203$ & $29,251,723$ \\
\hline 2014 & $44,716,211$ & $26,376,414$ & $2,616,436$ & $73,709,061$ \\
\hline 2015 & $26,800,442$ & $25,326,146$ & $1,868,420$ & $53,995,008$ \\
\hline
\end{tabular}

Source: Directorate General Of Air Transportation

Arriving Passengers (Model Pull Movement)

Linear regression analysis of the graph (Figure 1) were obtained the equations for the number of passengers departing $Y=2,047,726 X+$ $23,801,169$ and the value of the correlation of $R^{2}=0.089$. From the graph of the Exponential regression analysis (Figure 2) obtained equation for number of passengers departing $Y=23,174,543 e^{0062 X}$ and the value of the correlation of $R^{2}=0.060$. From the graph of a Polynomial regression analysis (Figure 3) were obtained the equations for the number of passengers departing $Y=-$ 
$11,272 x^{2}+2,092,814 x+23,778,625$ and the value of the correlation of $R^{2}=$ 0.089 .

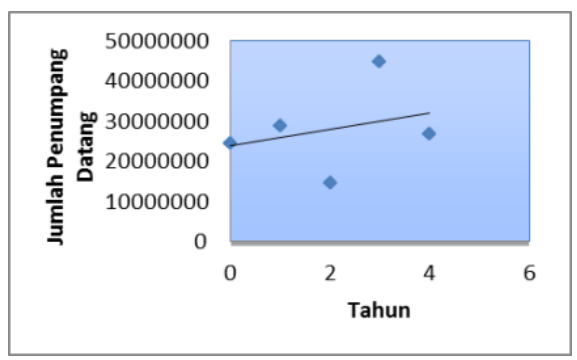

Figure 1. Linier Trend of Arrival Passanger

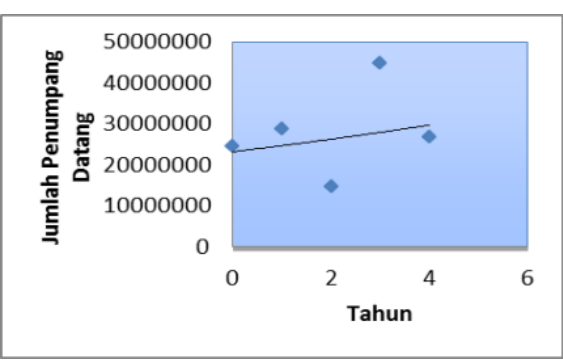

Figure 2. Exponential Trend of Arrival Passanger

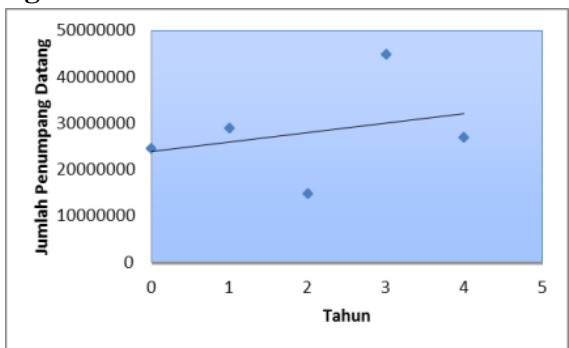

Figure 3. Polynomial Trend of Arrival

Departing Passengers (Model Generation Movement)

Linear regression analysis of the graph (Figure 4) obtained equation for number of passengers departing $\mathrm{Y}=581,650 \mathrm{x}+21,465,903$ and the value of the correlation of $\mathrm{R}^{2}=0.027$. From the graph of the Exponential regression analysis (Figure 5) were obtained the equations for the number of passengers departing $\mathrm{Y}=20,903,932 \mathrm{e}^{0.024 \mathrm{x}}$ and the value of the correlation of $\mathrm{R}^{2}=0.016$. From the graph of a Polynomial regression analysis (Figure 6) obtained equation for number of passengers departing $Y=1,293,985 \mathrm{x}^{2}$ $4,594,289 x+24,053,873$ and the value of the correlation of $R^{2}=0.217$.

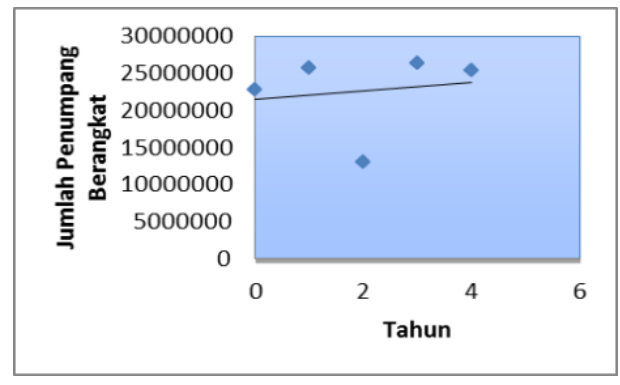

Figure 4. Linier Trend of Depart Passanger

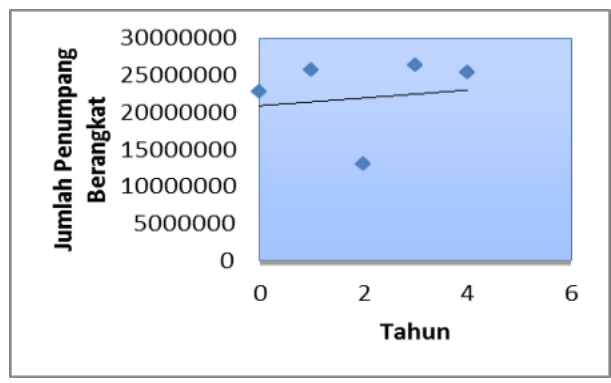

Figure 5. Exponential Trend of Depart Passanger 


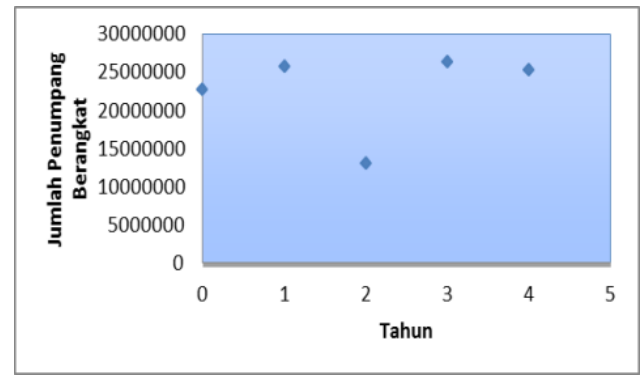

Figure 6. Polynomial Trend of Depart

Transit Passengers

Linear regression analysis of the graph (Figure 7) were obtained the equations for the number of passengers departing $\mathrm{Y}=-266,725 \mathrm{x}+$ $2,983,313$ and the value of the correlation of $R^{2}=0.366$. From the graph of the Exponential regression analysis (Figure 8) obtained equation for number of passengers departing $\mathrm{Y}=2,939,562 \mathrm{e}^{-0.108} \mathrm{x}$ and the value of the correlation of $\mathrm{R}^{2}=0.328$. From the graph of a Polynomial regression analysis (Figure 9) obtained equation for number of passengers departing Y $=24,754 \mathrm{x}^{2}-365,743 \mathrm{x}+3,032,822$ and the value of the correlation of $\mathrm{R}^{2}=$ 0.371 .

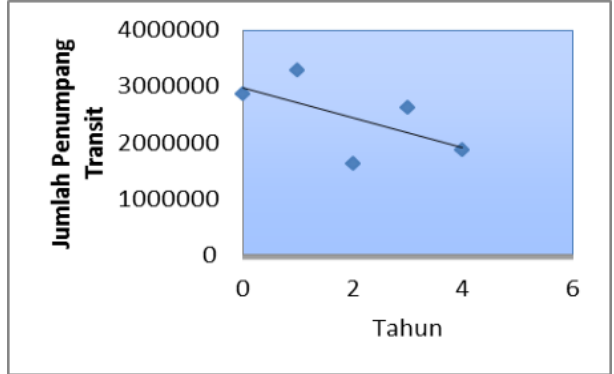

Figure 7. Linier Trend of Transit Passanger

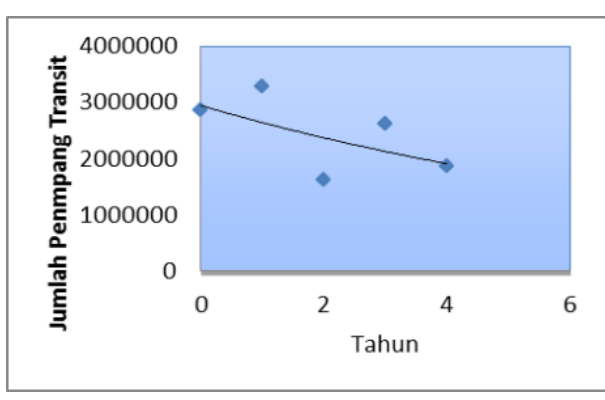

Figure 8. Exponential Trend of Transit Passanger

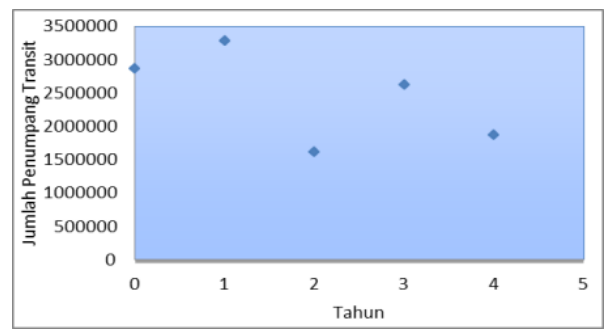

Figure 9. Polynomial Trend of Transit Passenger 
Trend Analysis models for Cargo

Linear regression analysis of the graph (Figure 10) retrieved amount of cargo equation $\mathrm{Y}=13,484,143 \mathrm{x}+485,830,925$ and the value of the correlation of $\mathrm{R}^{2}=0.013$. From the graph of the Exponential regression analysis (Figure 11) retrieved amount of cargo equation $\mathrm{Y}=$ $447,011,762 \mathrm{e}^{0.024 \mathrm{x}}$ and the value of the correlation of $\mathrm{R}^{2}=0.005$. From the graph of a Polynomial regression analysis (Figure 12) obtained the number of equations in $\mathrm{Y}=50,462,439 \mathrm{x}^{2}-188,365,612 \mathrm{x}+586,755,803$ and the value of the correlation of $\mathrm{R}^{2}=0.262$.

Table 2. The amount of Cargo airport of Soekarno-Hatta 2011-2015

\begin{tabular}{|c|c|c|c|}
\hline \multirow{2}{*}{ Years } & \multicolumn{2}{|c|}{ The Amount Of Cargo } & \multirow{2}{*}{ Total } \\
\cline { 2 - 3 } & Unloading & Loading & \\
\hline 2011 & $198,126,830$ & $334,015,788$ & $532,142,618$ \\
\hline 2012 & $263,571,608$ & $371,178,586$ & $634,750,194$ \\
\hline 2013 & 0 & $181,860,754$ & $181,860,754$ \\
\hline 2014 & $241,746,981$ & $354,861,144$ & $596,608,125$ \\
\hline 2015 & $242,459,952$ & $376,174,417$ & $618,634,369$ \\
\hline
\end{tabular}

Source: Directorate General Of Air Transportation

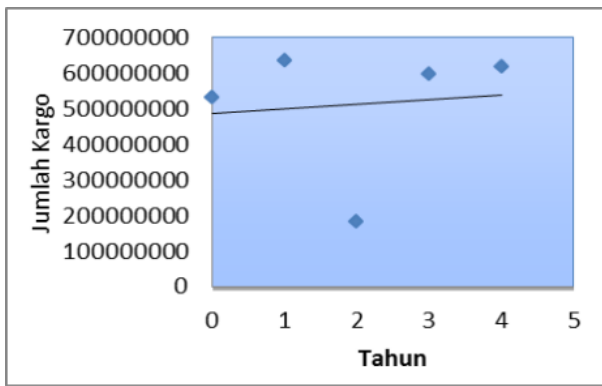

Figure 10. Linier Trend of Cargo

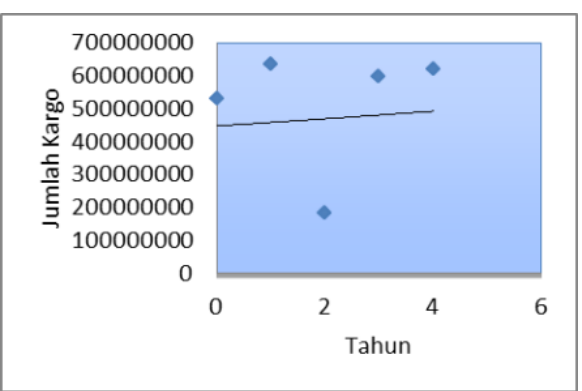

Figure 11. Exponential Trend of Cargo

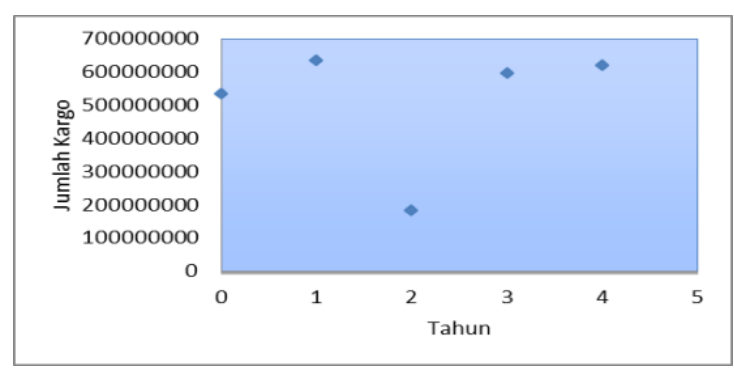

Figure 12. Polynomial Trend of Cargo 
Methods Of Market Analysis (Market Share Analysis)

This method describes the movement of the markets Division patterns regarding passengers between the airport i.e. Halim Perdana Kusuma Airport by Soekarno-Hatta (table 3). Based on the study of market patterns, with a model of trend analysis (Figure 13-15).

Table 3. The percentage of passengers at Soekarno-Hatta Airport and Halim Perdana Kusuma years 2011-2015

\begin{tabular}{|c|c|c|c|}
\hline \multirow[b]{2}{*}{ Years } & \multicolumn{2}{|c|}{ The Number Of Departing Passenger } & \multirow{2}{*}{$\begin{array}{c}\text { The percentage of } \\
\text { Soekarno-Hatta } \\
\text { passenger against } \\
\text { passenger Halim Perdana } \\
\text { Kusuma }(\%)\end{array}$} \\
\hline & Soekarno-Hatta & $\begin{array}{c}\text { Halim Perdana } \\
\text { Kusuma }\end{array}$ & \\
\hline 2011 & $22,757,324$ & 69,400 & 32.792 \\
\hline 2012 & $25,697,550$ & 101,769 & 25.251 \\
\hline 2013 & $12,988,593$ & 13,353 & 97.271 \\
\hline 2014 & $26,376,414$ & 779,300 & 3.385 \\
\hline 2015 & $25,326,146$ & $1,363,775$ & 1.857 \\
\hline
\end{tabular}

Source: Directorate General Of Air Transportation

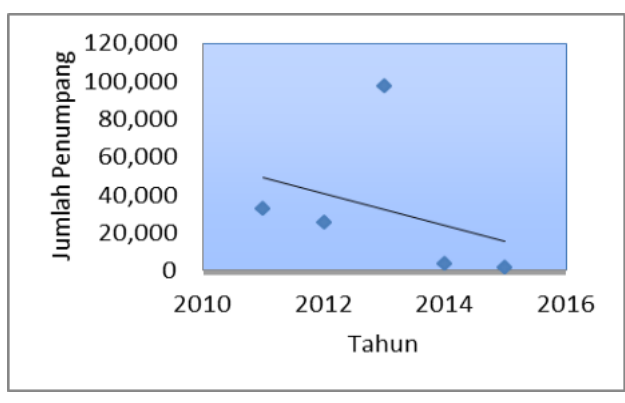

Figure 13. Linier Trend of Depart Passanger

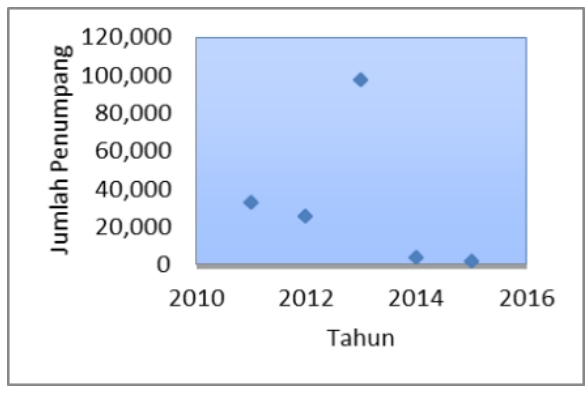

Figure 14. Exponential Trend of Depart Passanger

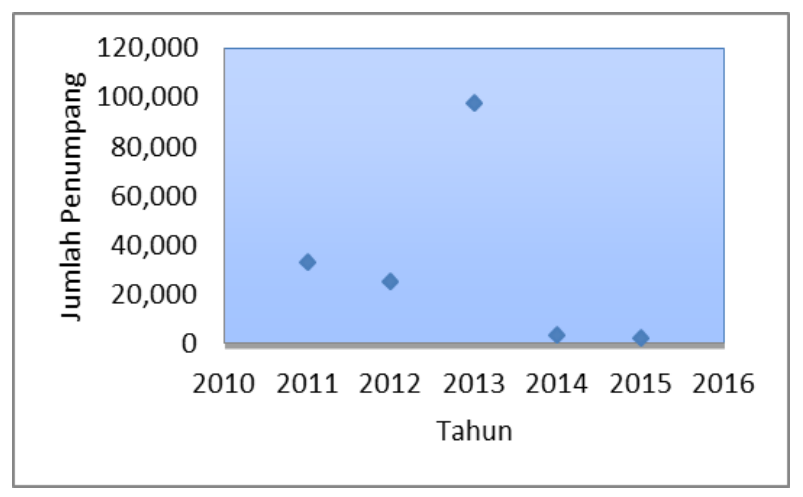

Figure 15. Polynomial Trend of Depart Passanger 
Recap of the obtained models

Based on the analysis conducted above to get the best forecasting where the results of the forecasting models are presented in the table 4-5.

Table 4. Forecasting for the growth of passengers and goods/cargo model based on trend analysis

\begin{tabular}{|c|c|c|c|}
\hline \multicolumn{4}{|c|}{ Model Number Of Passengers Comes } \\
\hline No. & Forecasting Model & The Regression Equation & $\begin{array}{c}\text { The } \\
\text { Value Of } \\
R^{2}\end{array}$ \\
\hline 1 & Linear Regression & $Y=2,047,+726 X 23,801,169$ & 0.089 \\
\hline 2 & $\begin{array}{l}\text { Exponential } \\
\text { Regression }\end{array}$ & $\mathrm{Y}=23,174,543 \mathrm{e}^{0.062 \mathrm{X}}$ & 0.060 \\
\hline 3 & $\begin{array}{l}\text { Polynomial } \\
\text { Regression }\end{array}$ & $Y=-11,272 x^{2}+814 x, 2,092+23,778,625$ & 0.089 \\
\hline \multicolumn{4}{|c|}{ Model Number Of Passengers Departing } \\
\hline No. & Forecasting Model & The Regression Equation & $\begin{array}{c}\text { The } \\
\text { Value Of } \\
R^{2}\end{array}$ \\
\hline 1 & Linear Regression & $Y=581,650 x+21,465,903$ & 0.027 \\
\hline 2 & $\begin{array}{l}\text { Exponential } \\
\text { Regression }\end{array}$ & $\mathrm{Y}=20,903,932 \mathrm{e}^{0.024 \mathrm{x}}$ & 0.016 \\
\hline 3 & $\begin{array}{l}\text { Polynomial } \\
\text { Regression } \\
\end{array}$ & $Y=1,293,985 x^{2}-4,594,289 x+24,053,873$ & 0.217 \\
\hline \multicolumn{4}{|c|}{ The Model Number Of The Transit Passengers } \\
\hline No. & Forecasting Model & The Regression Equation & $\begin{array}{c}\text { The } \\
\text { Value Of } \\
R^{2}\end{array}$ \\
\hline 1 & Linear Regression & $Y=-266,725 x+2,983,313$ & 0.366 \\
\hline 2 & $\begin{array}{l}\text { Exponential } \\
\text { Regression }\end{array}$ & $\mathrm{Y}=2,939,562 \mathrm{e}^{-0.108 x}$ & 0.328 \\
\hline 3 & $\begin{array}{l}\text { Polynomial } \\
\text { Regression }\end{array}$ & $Y=24,754 x^{2}-365,743 x+3,032,822$ & 0.371 \\
\hline \multicolumn{4}{|c|}{ The Model Number Of The Goods } \\
\hline No. & Forecasting Model & The Regression Equation & $\begin{array}{c}\text { The } \\
\text { Value Of } \\
R^{2}\end{array}$ \\
\hline 1 & Linear Regression & $Y=143 x+485,830,925,13,484$ & 0.013 \\
\hline 2 & $\begin{array}{l}\text { Exponential } \\
\text { Regression }\end{array}$ & $\mathrm{Y}=447,011,762 \mathrm{e}^{0.024 \mathrm{x}}$ & 0.005 \\
\hline 3 & $\begin{array}{l}\text { Polynomial } \\
\text { Regression }\end{array}$ & $\begin{array}{c}Y=50,462,439 x^{2}-188,365,612 x+ \\
586,755,803\end{array}$ & 0.262 \\
\hline
\end{tabular}

Source: data analysis

The results of the Projections on the future 
Some of the methods used, the equations that best meets the for use in forecasting traffic passengers, baggage and cargo are as follows.

Table 5. Prediction of the number of passengers year Soekarno-Hatta 2015-2025

\begin{tabular}{|c|c|c|c|c|}
\hline \multirow{2}{*}{ Years } & \multicolumn{3}{|c|}{ The Number Of Passengers } & \multirow{2}{*}{ Total } \\
\cline { 2 - 4 } & Arrive & Depart & Transit & \\
\hline 2015 & $26,800,442$ & $25,326,146$ & $1,868,420$ & $53,995,008$ \\
\hline 2016 & $33,960,895$ & $33,432,053$ & $1,822,957$ & $69,215,905$ \\
\hline 2017 & $35,929,717$ & $43,071,599$ & $1,729,508$ & $80,730,824$ \\
\hline 2018 & $37,875,995$ & $55,299,115$ & $1,685,567$ & $94,860,677$ \\
\hline 2019 & $39,799,729$ & $70,114,601$ & $1,691,134$ & $111,605,464$ \\
\hline 2020 & $41,700,919$ & $87,518,057$ & $1,746,209$ & $130,965,185$ \\
\hline 2021 & $43,579,565$ & $107,509,483$ & $1,850,792$ & $152,939,840$ \\
\hline 2022 & $45,435,667$ & $130,088,879$ & $2,004,883$ & $177,529,429$ \\
\hline 2023 & $47,269,225$ & $155,256,245$ & $2,208,482$ & $204,733,952$ \\
\hline 2024 & $49,080,239$ & $183,011,581$ & $2,461,589$ & $234,553,409$ \\
\hline 2025 & $50,868,709$ & $213,354,887$ & $2,764,204$ & $266,987,800$ \\
\hline
\end{tabular}

Source: data analysis

Table 6. Prediction of the amount of cargo Soekarno-Hatta 2015-2025

\begin{tabular}{|l|l|}
\hline \multicolumn{1}{|c|}{ Years } & \multicolumn{1}{c|}{ Cargo } \\
\hline 2015 & $618,634,369$ \\
\hline 2016 & $906,488,718$ \\
\hline 2017 & $1,273,209,935$ \\
\hline 2018 & $1,740,856,030$ \\
\hline 2019 & $2,309,427,003$ \\
\hline 2020 & $2,978,922,854$ \\
\hline 2021 & $3,749,343,583$ \\
\hline 2022 & $4,620,689,190$ \\
\hline 2023 & $5,592,959,675$ \\
\hline 2024 & $6,666,155,038$ \\
\hline 2025 & $7,840,275,279$ \\
\hline
\end{tabular}

Source: data analysis

Prediction Of Needs For Passenger Traffic

For projections of passenger traffic that comes, departing or transit (table 9), each selected the biggest korelasinya models, with the resulting equation:

1. Predictions for Passengers who arrive using Model Trend Analysis with Polynomial Regression equation, i.e.:

$Y=-11,272 x^{2}+2,092,814 x+23,778,625$ with $R^{2}=0.089$ 
2. Predictions for passengers who set off using a Model Trend Analysis with Polynomial Regression equation, i.e.: $Y=1,293,985 x^{2}-4,594,289 x+24,053,873$ with $R^{2}=0.217$

3. Predictions for Passenger Transit using Model Trend Analysis with Polynomial Regression equation, i.e.: $\mathrm{Y}=24,754 \mathrm{x}^{2}-365,743 \mathrm{x}+3,032,822$ with $\mathrm{R}^{2}=0.371$

\section{Prediction Of Cargo Traffic Forecasting Needs}

The method used is a Model Trend Analysis with Polynomial Regression equations, with the resulting equations (table 6):

$$
\mathrm{Y}=50,462,439 \mathrm{x}^{2}-188,365,612 \mathrm{x}+586,755,803 \text { with } \mathrm{R}^{2}=0.262
$$

\section{Conclusion}

1. Based on the results of the analysis that has been done and the value of the correlation coefficient is produced, it can be shown that the forecasting of passenger growth of Soekarno-Hatta in the future by using Trend Model Analysis of the correlation coefficient value produces the largest, which means there are shows a very strong relationship between variables $\mathrm{X}$ and $\mathrm{Y}$ as well as if viewed from the value of $\mathrm{R}^{2}$ obtained shows that the Model of Trend Analysis better and the fit of the Model on Market Share.

2. Once done the calculations and analysis, Trend Analysis Method is a method that is best used to predict growth in the future, in this case the growth of passenger numbers and cargo Airport Soekarno-Hatta Airport. As for the model Equations for the number of passengers arriving $\mathrm{Y}=-11,272 \mathrm{x}^{2}+814 \mathrm{x}+23,778,625,2,092$ with $\mathrm{R}^{2}=0.089$, model equations for the number of passengers departing $\mathrm{Y}=$ $1,293,985 x^{2}-289 x+24,053,8734,594$, with $R^{2}=0.217$, equation models for the number of passengers transiting $\mathrm{Y}=24,754 \mathrm{x}^{2}-365,743 \mathrm{x}$ $+3,032,822$, with $R^{2}=0.371$, and equation models for the number of goods/cargo $\mathrm{Y}=50,462,439 \mathrm{x}^{2}-612 \mathrm{x}+586,755,803188,365$, with $\mathrm{R}^{2}$ $=0.262$. 
3. By using the method of Trend analysis it can be concluded that the growth in passengers and cargo at the Soekarno-Hatta Airport within the next 10 years will experience increased and with the forecast or projection It then expected Soekarno-Hatta Airport can prepare to deal with such growth by improving services and airport facilities.

\section{References}

Arman, Hakim Nasution. 2006. Manajemen Industri. Yogykarta: Andi.

Damardjati, RS. 2001. Istilah-istilah Dunia Pariwisata. Jakarta: Pradnya Paramita.

Majid, S.A. dan Warpani, E.P.D. 2010. Ground Handling Manajemen Pelayanan Darat Perusahaan Penerbangan. Jakarta: Rajawali Pers.

Ricardianto, Ricky P., Kuntohadi, Hendro., Rifni, Muhammad. 2014. Air Cargo Capacity on Cargo Terminal Development Plan at SoekarnoHatta International Airport.

Taylor III, Bernard W. (2005). Sain Manajemen (Judul Asli: Introduction to Management Science, Diterjemahkan Oleh Chaerul D. Djakman, dkk), Jilid Satu. Edisi Kedelapan. Jakarta: Salemba 4.

Trimukti, Elsa. 2010. Analisis Model Kebutuhan Pergerakan Penumpang dan Barang Bandara Rahadi Oesman Ketapang.

http://hubud.dephub.go.id/?id/llu/index/filter:airport,222 (downloaded on November $7^{\text {th }}, 2017$ ) 